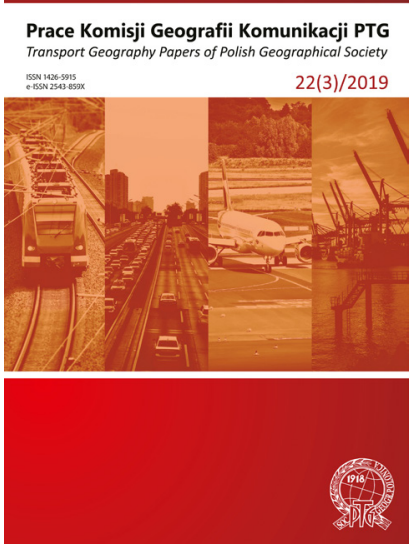

Transport Geography Papers of Polish Geographical Society

$2019,22(3), 41-52$

DOI: 10.4467/2543859XPKG.19.016.11282

Received: 09.08.2019

Received in revised form: 20.09 .2019

Accepted: 20.09.2019

Published: 30.09 .2019

\title{
TRANSPORT ACCESSIBILITY TO RECREATIONAL SPACE IN CITIES FOR SENIOR CITIZENS ON THE EXAMPLE OF ZAWADZKIEGO-KLONOWICA MUNICIPAL NEIGHBOURHOOD IN SZCZECIN
}

\section{Dostępność transportowa przestrzeni rekreacyjnej miast dla seniorów na przykładzie Osiedla Zawadzkiego-Klonowica w Szczecinie}

\author{
Agnieszka Sawińska \\ Faculty of Economics, Finance and Management, University of Szczecin, Cukrowa 8, 71-004 Szczecin, Poland \\ e-mail: agnieszka.sawinska@usz.edu.pl
}

\section{Citation:}

Sawińska A., 2019, Transport accessibility to recreational space in cities for senior citizens on the example of ZawadzkiegoKlonowica municipal neighbourhood in Szczecin, Prace Komisji Geografii Komunikacji PTG, 22(3), 41-52.

\begin{abstract}
One of the elements affecting the quality of life is recreational activity. Considering the ageing demographic structure of urban residents, it is necessary to take into account the needs and expectations of seniors in the activities of cities. In addition, an important factor determining recreational activity is the transport accessibility of the recreational space of cities on which this article is focused. The article consists of three parts. The first explains the theoretical issues regarding transport accessibility. The second presents considerations on the mobility of seniors. The supplement to the discussion is the third part, which is a case study for the Zawadzkiego-Kolonowica housing estate in Szczecin (Poland), whose age structure shows a high level of ageing.
\end{abstract}

Key words: quality of life, transport accessibility, recreation, senior, city, Szczecin 


\section{Introduction}

A particularly important goal of urban development is to improve the quality of life of residents. The concept of quality of life is therefore multidimensional. It can relate to economic (material well-being) and noneconomic (immaterial aspects of life situations such as health, social relations, and quality of the environment). In addition, the quality of life can be assessed both on the basis of objective features - living conditions and subjective assessments of these living conditions (Panek, Zwierzchowski, 2019). The domains of quality of life include material living conditions, economic activity and working conditions, health, education, leisure and social relations, economic and physical security, the state and basic rights, environmental quality and subjective well-being (Report of the Task..., 2011). Recreation is therefore a field of human activity that has a significant impact on the objective and subjective dimension of life if its quality depends on the material, social, physical and emotional well-being felt (Śniadek, Zajadacz, 2014). In the face of demographic trends, especially the ageing of city residents, the challenge. is not only senior citizens social activation and their free time organisation, but also adjustment of many spheres of the city's operations to abilities changing with age, including transportation. An important factor determining the recreational activity of senior citizens in cities is transport accessibility to recreational space in cities. The needs and expectations of senior citizens in terms of transport accessibility may differ significantly from the needs of the general public, as indicated, inter alia, by Raczyńska-Buława (2017). The identification of needs and expectations of senior citizens and their inclusion in the public transport system may become a symbol of a modern city, which in turn will increase the comfort of transport not only for senior citizens, but also for other residents of the city.

The aim of the article is defining the assumptions for further research on the availability of recreational space in cities for senior citizens, and determining the legitimacy of conducting such research. Therefore, the article is divided into three parts. The first part is of a theoretical nature and focuses on the essence of transport accessibility to urban recreational space. The second part reviews the literature on shaping transport accessibility, with particular emphasis being put on the group of senior citizens. The third part is a case study and an attempt to analyse the transport accessibility to selected recreational areas of the city of Szczecin for senior citizens - residents of Zawadzkiego-Klonowica municipal neighbourhood, the administrative unit of Dzielnica Zachód (West District).

\section{Transport accessibility to recreational space in cities - theoretical aspects}

Recreational space of a city should be understood as an area particularly predisposed to recreational activity. In addition to the environmental determinants associated with recreational resources, the infrastructure and services provided in the field of recreation are of key importance for the implementation of recreational activities. The infrastructure mainly includes specialized elements of development, among others (Sawińska, 2018):

- elements of physical recreation infrastructure, including: stadiums, playing fields, sports halls, gyms, recreational areas with equipment for physical recreation (e.g. "open gyms"), swimming pools, bathing beaches, tennis courts, harbours and marinas, marinas for kayaks, health paths, water, walking and cycling trails, walking routes;

- elements of natural environment landscape feature development and display, including forests, parks, green areas;

- elements of cultural infrastructure, including: cinemas, theatres, concert halls, art galleries;

- elements of cultural and historical infrastructure, including museums, historical objects and architectural complexes, cultural heritage objects (sculptures and memorial monuments);

- elements of entertainment infrastructure, including amusement parks, funfairs.

On the other hand, services related to recreational activities include services provided by gyms, fitness clubs, swimming pools, dance schools, wellness and spa facilities as well as rental of recreational equipment.

The use of the city's recreational infrastructure depends on its transport accessibility. In the literature on the subject, transport accessibility is defined differently depending on whether its problems are discussed by geographers, city planners or economists. A broad review of the concept of "transport accessibility" was carried out by Bocheński (2018). One of the definitions cited by the author is the definition by Dalvi and Martin from 1976, according to which availability is understood as ease with which any land-use activity can be reached from a location with the use of a particular transport system. On the other hand, Dawid (2019), by referring to Hansen (1959), defined accessibility as a measurement of space adapted to the pedestrian's possibilities of covering distance while taking into account barriers and limitations. Furthermore, Dawid (2019) noted that access to recreation areas and services results from the way the land is developed, with additional elements 
affecting accessibility being land morphology and psychological factor. In the case of older people's behaviour, long-term habits may play a significant role. Whereas Komornicki and co-authors (Komornicki et al., 2009) noted that transport accessibility can be identified with spatial accessibility if certain conditions are met, among which they mentioned the possibility of measuring time and distance, the ability to analyse the differences in accessibility resulting from individual features of the transport network user, and the ability to measure infrastructure in a given area.

As underlined by Kwarciński (2013), accessibility is a criterion for assessing the operation of public transport system, while the improvement of accessibility is conditioned by the development, extension or modernization of transport infrastructure. In the area of analysis related to transport accessibility, the author distinguishes the term "transport service accessibility" and "transport accessibility". In his opinion, the condition for the development of transport accessibility to a given area is primarily the improvement of linear transport infrastructure, whereas the condition for the development of transport service accessibility is the development and increase in the number of transport points, as well as the development of transport offer.

The literature on the subject also pays special attention to transport accessibility components such as transport, space, time and individual. The transport component reflects the possibility of travelling between two points in space defined as a transport mode. The spatial component applies to the development of space. Transport system users may differently assess accessibility, depending on the time of travel (time component) and their individual socioeconomic characteristics (individual component) (Sierpiński, 2010; Bocheński, 2018; Komornicki et al., 2009).

Among the measures of transport accessibility, the literature also distinguishes other methods of assessing transport accessibility (Komornicki et al., 2009):
- availability measured by infrastructure equipment, implemented by using infrastructure equipment indicators of a given area,

- availability measured by distance using direct, actual physical, time or economic distance to the destination or set of destinations,

- availability measured by isochrones, determined by estimating a set of destinations available at a given time or at a particular cost or effort of travel,

- availability measured in time-space geography, obtained by comparing alternative travel paths between a starting point and destination,

- availability measured by utility maximization, determined individually based on the behaviour of transport system users.

The deliberations discussed in the article have been limited to the transport accessibility to recreational area and narrowed to public transport in internal terms (transport within the city). It was assumed that the availability of public (mass) transport means an ease of reaching public transport and using it in order to get to the destination (OIszewski et al., 2013), which in the analysed case will be recreation areas. In the case of a detailed analysis of the time availability of public transport, the following should be taken into account:

- travel time (on foot or by car) to the means of transport (bus stop, stations, etc.);

- frequency of the means of transport - number of runs (connections) per unit of time, e.g. hour, day, etc.;

- journey time by means of transport 1;

- possible change when there is no direct connections (waiting time);

- journey time by means of transport 2;

- travel time (on foot or by car) from the means of transport

The above elements are considered availability indicators in terms of time attribute (Bocheński, 2018). In the case of public transport, other components of public passenger transport, presented in Tab. 1 should also be noted.

Tab. 1. Components of passenger transport.

\begin{tabular}{|c|c|}
\hline Element & Transport component \\
\hline Time & $\begin{array}{l}\text { - } \quad \text { waiting time for the means of transport, } \\
\text { - } \quad \text { travel time (by the means of transport) including waiting time for getting on and off the vehicle, } \\
\text { - } \quad \text { waiting time for transfers. }\end{array}$ \\
\hline Cost & - $\quad$ ticket price. \\
\hline Effort & $\begin{array}{ll}- & \text { level of (dis)comfort, } \\
- & \text { physical effort, } \\
- & \text { reliability, } \\
- & \text { stress, } \\
- & \text { information (e.g. reading the timetable), } \\
- & \text { social security. }\end{array}$ \\
\hline
\end{tabular}


In addition to the appropriate transport infrastructure, including its location, a factor ensuring an increase in integration between transport modes is also the proper organization of transport services, which ensures their integration, so that the arrival time of one means of transport and departure of the other is acceptable to the passenger (Kwarciński, 2013).

\section{Mobility of the elderly in cities}

The needs of the elderly in the field of transport accessibility have been, in recent years, a point of interest of an increasing number of people, including scientists, practitioners and politicians. This is reflected in scientific publications, research projects or strategic documents.

As emphasized by Komsta et al. (2017), the World Health Organization (WHO) already listed Transport as one of eight areas of the functioning of an agefriendly city. In 2007, the WHO proposed the following list of control factors defining the characteristics of age-friendly transport (senior citizen-friendly) (Shiau, Huang, 2014):

- Affordability: public transportation is affordable to all older people, and transportation rates are transparent and well-displayed;

- Reliability and frequency: public transport is reliable and frequent;

- Travel destinations: public transport is available for older people to reach key destinations such as hospitals, health centres, public parks, shopping centres, banks and seniors' centres;

- Age-friendly vehicles: accessible with lower, low steps floors and wide and high seats; clean and well-maintained, clear signage indicating the vehicle number and destination;

- Specialised services are available for people with disabilities;

- Priority seating for older people: provided and respected by other passengers;

- Transport drivers: courteous, obey traffic rules, stop at designated transports stops, wait for passengers to be seated before driving off and park alongside the curb so that it is easier for older people to step off the vehicle;

- Safety and comfort;

- Transport stops: located in close proximity to where older people live, provided with seating and with shelter from the weather, clean and safe, adequately lit;

- Information: provided to older people on how to use public transport and about the range of transport options available; time tables are legible and easy to access clearly indicating the routes of buses accessible to disabled people.
Ways of improving the mobility of the elderly were also indicated in the research report conducted in 2011-2013 by the University of Plymouth and financed through the EU project TRACY. The report contains recommendations for governments to take further actions aimed at developing transport policies that will enable people over 65 to sustain mobility and stay active. The international evaluation covered a total of 146 documents from 29 countries that can be classified as part of the EU guidelines on "people with reduced mobility". Researchers have found that policy makers at EU and national level put a disproportionate emphasis on safety, affordability and accessibility for people with disabilities (without barriers), while a comprehensive approach can actually translate into a significant increase in older people's mobility. Moreover, J. Shaw, the main author of the report, stressed that improving the quality of the transport system for the elderly essentially means an improvement for everyone'. The recommendations included in the report largely coincide with the parameters indicated by the WHO. The guidelines on transparency and complementarity of policies deserve additional attention. Transparency is understood as measures to increase the awareness of the elderly regarding the available transport options and their understanding of the possibilities of using them. In turn, complementarity concerns supporting a transport system and mobility through policies that work alongside it. This is to further promote the improvement of accessibility for the elderly (TRACY, Transport needs for..., 2013).

Raczyńska-Buława (2017a, 2017b) made a broad description of selected problems concerning transport accessibility of the elderly. In her deliberations, the author presented barriers related to the mobility of older people. She pointed out, among others, that currently the elderly constitute about $30 \%$ of passengers, and within 20 years this percentage will increase to $50 \%$. The author rightly pointed out that senior citizens constitute the most heterogeneous group, differing in preferences, level of fitness, health or lifestyle. Moreover, it is a group that is very often underestimated and affected by prejudice. Raczyńska-Buława (2017a) discussed the necessity to change the current way of thinking about planning and management of the public transport network and start paying more attention to the problem of the elderly. The author, when describing travel behaviour of senior citizens, indicated that older people very often remain outside the public transport system and travel by car - as passengers or drivers.

https://cordis.europa.eu/news/rcn/128538/pl [15.07.2019] 
At an older age, when they are not able to drive their own car, they often become isolated, give up travelling or limit it due to the inconvenience of planning the travel process and the need to overcome barriers to access transport (physical, mental and other). An important issue, from the point of view of the subject of considerations, is the Author's statement saying that changes in transport behaviour and a significant limitation of possibilities may have serious consequences for the elderly. Reducing the number of journeys may lead to limiting personal contacts with family and friends, as well as changing the way of spending free time. Physical activity and interactions with people are consequently replaced by watching television, doing crosswords or listening to the radio (Raczyńska, 2017a).

The subject of the importance of public transport in shaping a city friendly to the elderly was also taken up by Komsta et al. (2017). In their considerations, they drew attention to solutions supporting the improvement of public transport accessibility for the elderly regarding transport infrastructure, improvement of financial availability and information about services and transport system (routes, location of stops, ways of travelling on the given route) as well as the implementation of these services (e.g. frequency, punctuality). They also addressed the problem of qualifications and training of public transport system workers (drivers and other people), especially in the provision of services for the elderly and the disabled, both in the areas of benevolent treatment and the correct use of all technical and operational possibilities of modern means of transport. Moreover, they noticed that in the process of cost-benefit analysis regarding improvement of accessibility of people with limited mobility to public transport, technical-operational and organizational solutions, which are applied to elderly and disabled people, are increasingly improving the accessibility of public transport also for all other passenger groups.

On the other hand, Trzpiot and Szołtysek (2015) analysed the preferences regarding the quality of life of senior citizens in the city. The authors, referring to the research conducted as part of the SIZE project, indicated that the structure of everyday mobility of senior citizens is similar throughout Europe. They pointed out that senior citizens want to be needed, but sometimes the obstacles of a physical nature, both caused by senior citizens themselves and the environment, stand in the way of this emotional sphere (Trzpiot, Szołtysek, 2015). Among the variables assessing the quality of life in the city, the authors also distinguished variables that can be attributed to transport accessibility to recreational space. These are variables related to culture and physical culture (e.g. access to public libraries, culture points (cinema, theatre), physical culture points (gym), possibility of performing active sport, opportunity and attractive leisure time) or variables concerning the organization of a meeting space with friends, organization of events in the city (concert, museum night, etc.). The group called the mobility variable includes, among others, indicators of the quality of life in the city such as: personal safety during travel (e.g. theft in means of transport), traffic safety of public transport vehicles, price of public transport ticket, access to public transport, access to cycle routes, quality of public transport, waiting conditions at stops (roof, seats, stops sheltered from the wind, etc.), travel conditions (standing places and sitting seats, crowd, cleanliness, temperature), separate lanes (for public transport), discounts on public transport fares, safety of the surroundings (street, bus stop, district). They also identified public space as an important variable in the lives of senior citizens in the city, while among the indicators of its assessment they mentioned, among others: the existence of a part of the city where people have unlimited possibility of meeting with others and transport accessibility to this space. As studies conducted by Trzpiot and Szołtysek (2015) showed, modern cities do not guarantee safe and comfortable life to senior citizens. Based on the conducted research and in addition to the recommendations for the health of senior citizens (broadly understood access to health services), the authors indicate that in the field of mobility, i.e. the ability to move or otherwise - overcome space - there is a tendency to combine the quality of life with measures that facilitate transport - generally, public transport. The conditions for waiting for a vehicle or transfer between vehicles, as well as the quality of public transport services and possible alternative modes of transport, were important. The financial conditions of transport turned out to be less important, which is probably related to the common discounts granted to senior citizens or free travel after reaching the age of 70 . Moreover, they stressed that the quality of public space is very important for senior citizens (Trzpiot, Szołtysek, 2015).

The needs of the elderly in the field of urban mobility are described by Solecka (2018). The author points out that public transport is often the only means of transport that the elderly can use, which results from the fact that these people are often unable to travel by personal transport vehicles as a driver due to their health problems. Similarly to the previously quoted authors, the author points out that the fear of travelling by means of public transport causes many older people to feel isolated, and thus not participate in social life. Solecka defines goals related to 
various types of services and recreational purposes as the main goals of the elderly people's journey. Among the problems of travelling by public transport the author mentions: problems with getting on and off public transport vehicles, high travel costs, low frequency of trips, low comfort of travel by public transport, poor lighting of stops, problems with using ticket machines, lack of easily accessible handrails and other handles in public transport vehicles, concerns about the lack of possibility of talking with vehicle operator, stress caused by haste, especially during rush hours. Moreover, the author states that public transport fails the older people and does not meet their basic expectations (Solecka, 2018).

On the other hand, Kruszyński and Żak (2017) stress that the growing demand for travel among an increasing number of people with disabilities and the elderly, who are at the same time becoming more and more active, should be satisfied by a properly designed transport offer which is transport supply. Such an offer should include the following, interrelated and properly matched elements: infrastructure (nodal and linear), means of transport, transport services and organization of transport (organizational structure, qualified employees, regulations, etc.). A transport system constructed in this way should be tailored to the needs of the elderly and the disabled. The authors also point out that the currently desirable so-called universal design in the field of urban transport must be preceded by the identification of existing barriers in the accessibility to urban infrastructure and means of transport for all city residents, with special focus being put on the needs and requirements of the disabled and the elderly. This is particularly important in regards to depopulation and ageing of population (Kruszyński, Żak, 2017).

\section{Analysis of transport accessibility to selected recreational places for the residents of Zawadzkiego-Klonowica municipal neighbourhood in Szczecin, with particular emphasis being put on the needs of the elderly - case study}

Szczecin is a city covering a large area (over $300 \mathrm{~km}^{2}$ ) with a diverse natural environment, in which water and green areas occupy a dominant share of the area (respectively $25 \%$ and $20 \%$ ). The city has numerous parks with a unique tree stand, monuments of material heritage, museums and port areas. The supply for recreational facilities in the city is constantly increasing and the city authorities attach great importance to the recreational function of the city. Residents of the city have many opportunities to spend their free time both outdoors and in closed facilities where rec- reational services are provided. However, it should be noted that the demographic structure of the city indicates the ageing of the population. At the end of 2018 , the number of people aged over 60 amounted to over $28 \%$ of the total population, which means an increase of $8 \%$ points when compared to 2008. The population of Szczecin is concentrated in four districts of the city, i.e. Północ, Zachód, Śródmieście and Prawobrzeże.

For the purposes of the case study, considerations regarding transport accessibility (public transport) were narrowed down to Zawadzkiego-Klonowica municipal neighbourhood that is part of Zachód district. It is $1.58 \mathrm{~km}^{2}$ and in 2018 the number of the residents was $11641 .^{2}$ The choice of the municipal neighbourhood was subjective and dictated by the ease of observation and the fact, that demographic structure shows the high level of ageing. People $60+$ represent $38 \%$ of citizens. It is $10 \%$ more than the city average. Moreover, it includes the oldest Nursing Home in Szczecin - "Dom Kombatanta i Pioniera Ziemi Szczecińskiej" ("The Home of a Veteran and Pioneer of the Szczecin Region"), which was put into public use in 1983, and is home for 251 residents $^{3}$. The neighbourhood was built using Plattenbau technology in the 1970's in Szczecin. It took its name from the two main communication streets of the neighbourhood. In the north-eastern part of the neighbourhood there is Puszcza Wkrzańska. The main streets are Aleksandra Zawadzkiego str. and Sebastiana Klonowica str. ${ }^{4}$ Within the neighbourhood, there is the Netto-Arena sports hall and the Municipal Athletic Stadium.

Zawadzkiego-Klonowica municipal neighbourhood should be considered as well connected with the rest of the city and its outskirts (Fig. 1).

Bus lines such as number 75 (Krzekowo - Dworzec Główny), 60 (Stocznia Szczecińska - Cukrowa), 53 (Stocznia Szczecińska - Pomorzany Dobrzyńska), 80 (Zakłady Piekarnicze - Ludowa), 105 (Klonowica Zajezdnia - Dobra Osiedle) run through its main streets. The number of bus stops located in the neighbourhood is 14 . In addition to bus routes, residents of the neighbourhood can use tram lines 1 (GłębokiePomorzany), 9 (Głębokie-Potulicka), 5 (KrzekowoLudowa), and 7 (Krzekowo-Turkusowa), whose stops are located on the border of the neighbourhood.

Although the number of stops is high, it should be noted that none of the stops located in the neigh-

http://geoportal.szczecin.pl [23.09.2019]

https://dpsromera.szczecin.pl/ [22.07.2019]

https://dzielniceszczecina.tv-polska.eu/film3/402763dzielnice-szczecina-z-drona---zawadzkiego-klonowica\# osiedla [22.07.2019] 


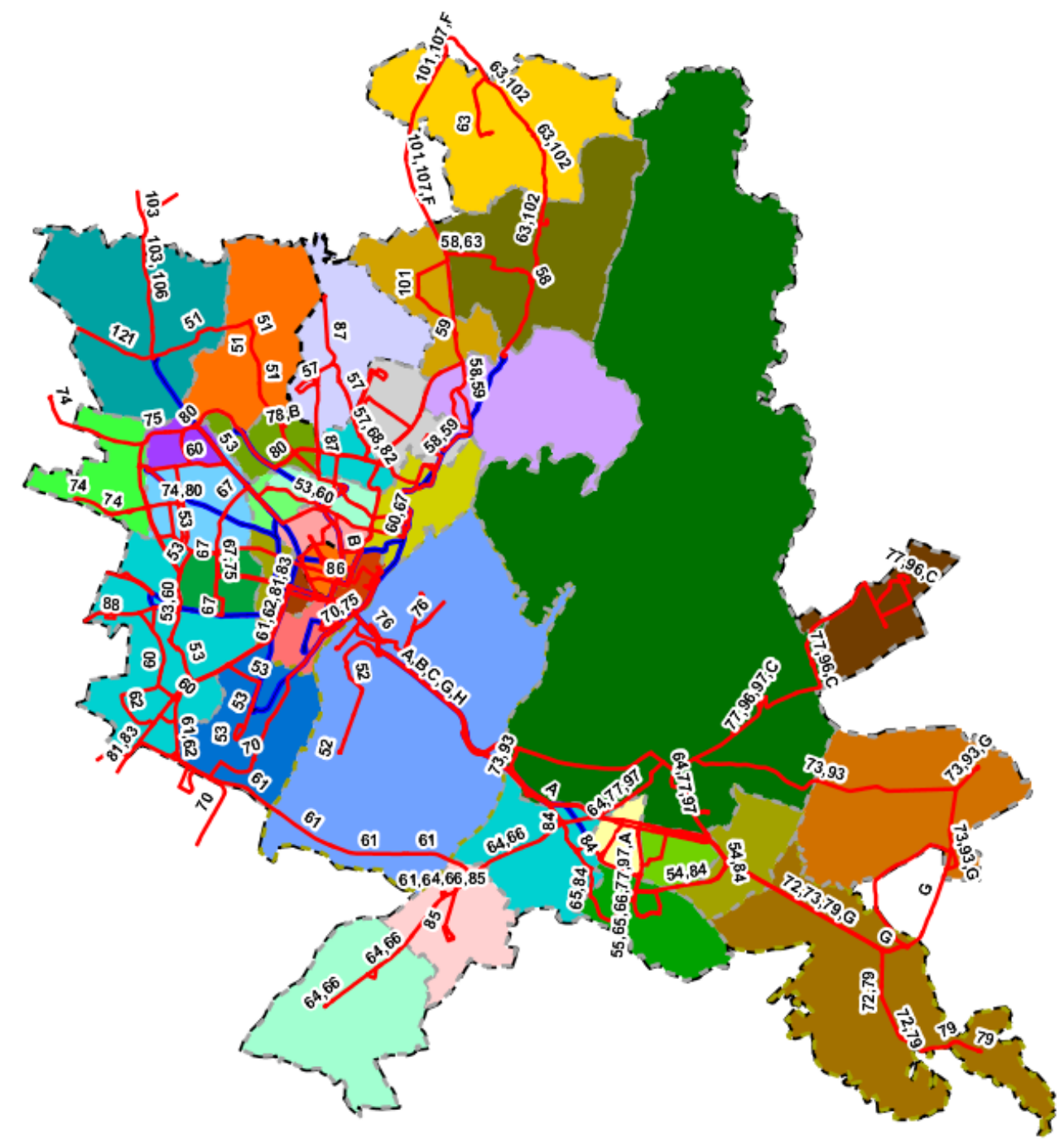

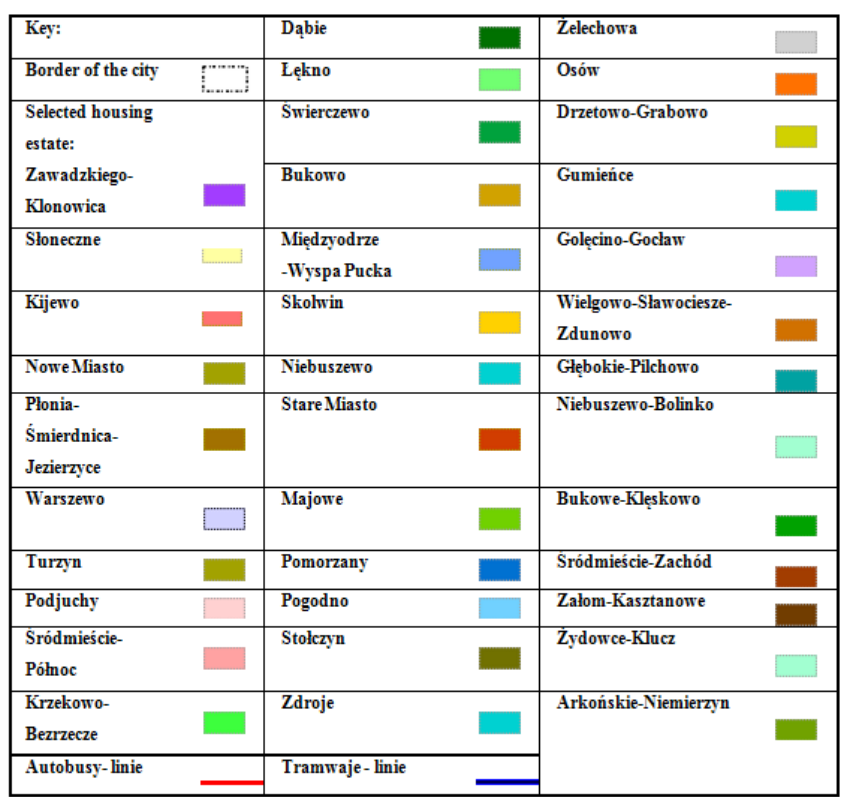

Fig. 1. Selected housing estates of Szczecin on the map of the city's transport network.

Source: own work based on http://geoportal.szczecin.pl [24.09.2019]. 
bourhood is equipped with electronic information boards. Most stops have a roof and a bench. At two stops located in the neighbourhood (Zawadzkiego and Unia Lubelska stops) there are stationary ticket machines that sell tickets. Stops are not adapted to the elderly in any way.

Assuming that in the case of the elderly low-floor buses are particularly important, the analysis of the number of daily trips served by particular lines whose route covers the described neighbourhood was analysed. Runs from 7 a.m. to 8 p.m. were taken into account, due to the fact that senior citizens avoid travelling in late hours. ed. The accessibility of Park Szachisty is very good - reaching the farthest part of the neighbourhood takes a maximum of 15 minutes. The second footpath also runs from the clinic to a commercial complex, and on its route there is also the above-mentioned Park Szachisty and the so-called Psia Polana (Dog's Glade), which has not yet been developed, but is a place of walks for the residents of the neighbourhood. The third footpath is a route along the main streets of the neighbourhood (Klonowica str., Zawadzkiego str., Szafera str., Marlicza str.). On its route, there is a Sports-Entertainment Hall next to which there can be found a fountain with resting places, an "open-air

Tab. 2. Bus and tram lines in Zawadzkiego-Klonowica municipal neighbourhood.

\begin{tabular}{|c|c|c|c|c|}
\hline & $\begin{array}{c}\text { The number of daily runs } \\
\text { in one direction covered by } \\
\text { low-floor rolling stock }\end{array}$ & $\begin{array}{c}\text { The total number } \\
\text { of runs between 7 } \\
\text { a.m.-8 p.m. }\end{array}$ & $\begin{array}{c}\text { The share } \\
\text { of low-floor } \\
\text { rolling stock }\end{array}$ & $\begin{array}{c}\text { Selected recreational places of residents of } \\
\text { Szczecin }\end{array}$ \\
\hline Line 75 & 44 & 106 & $41 \%$ & $\begin{array}{c}\text { City Centre, Helios Cinema, Anders Park, } \\
\text { Cathedral, The Port Gate, Piast Boulevard }\end{array}$ \\
\hline Line 60 & 33 & 46 & $71 \%$ & $\begin{array}{c}\text { Rose Garden, Summer Theatre, Kasprowicz } \\
\text { Park, Jasne Błonia, Municipal Cemetery }\end{array}$ \\
\hline Line 53 & 0 & 34 & $0 \%$ & $\begin{array}{c}\text { Arkoński Forest, Arkonka Beach, Arkonia } \\
\text { Stadium }\end{array}$ \\
\hline Line 1 & 40 & 48 & $83 \%$ & $\begin{array}{c}\text { Summer Theatre, Kasprowicz Park, Jasne Błonia, } \\
\text { Municipal Cemetery }\end{array}$ \\
\hline Line 9 & N/A & 47 & N/A & $\begin{array}{c}\text { Arkoński Forest, Arkonka Beach, Bicycle Track, } \\
\text { Głebokie Lake, Goplana Lake, City Centre, } \\
\text { Żeromski Park, Philharmonic hall }\end{array}$ \\
\hline
\end{tabular}

Source: own work based on the analysis of ZDTiM timetables: https://www.zditm.szczecin.pl [20.07.2019].

As shown in tab. 2, bus lines number 60 and 53 are serviced to a high degree by low-floor rolling stock, which may result from the fact that there is a hospital and a cemetery on the route. It should be noted that Central Cemetery because of its natural environment is an important place of recreation for senior citizens. The cemetery is the biggest necropolis in Poland/over 169 hectares/, and the third in Europe after Hamburg and Vienna. On the other hand, the lack of low-floor rolling stock on the route of bus line number 80 , although justified by technical reasons, i.e. renovation of the road surface, should be a signal for decisionmakers to find alternative solutions that facilitate the journey for the elderly. It is a route that connects the neighbourhood not only with Arkoński Forest, but also the hospital.

Senior citizens who live in Zawadzkiego-Klonowica municipal neighbourhood have the option of enjoy outdoor recreation in the neighbourhood on three footpaths. The first one connects the clinic with the church and runs through Park Szachisty (Chess Park), where the so-called "open-air gym", shaded benches and benches with chess tables are locat- gym", a skate park, a playground, a pitch and tennis tables. On the outskirts of the neighbourhood, there is also a park on Litewska str., which is equipped with an "open-air gym", benches and a fenced dog park. Distance between Park Szachisty and the park on Litewska str. is $950 \mathrm{~m}$, i.e. about a 17-minute walk.

Due to the fact that recreational activity of senior citizens is not limited to recreation inside the neighbourhood, based on the results of research conducted by the Institute of Tourism and Health Resort Management of Tourist Management Department at University of Szczecin in 2014 among Szczecin residents (Badania statutowe: Miasto jako..., no data), the most often chosen outdoor recreation areas were selected and their transport availability was then assessed. As research has shown, the most frequently chosen recreational places in the open air for people aged over 50 are Kasprowicz Park, Chrobry Embankment and Puszcza Bukowa (Beech Forest). In order to make a comparison, it was hypothetically assumed that the starting point for the senior citizen is the DPS Headquarters. Moreover, the same start time of travel was adopted, i.e. 9.00 a.m. The Google Map Planner was used for the study. 
Tab. 3. Selected possibilities of reaching Kasprowicz Park by the inhabitants of Zawadzkiego-Klonowica municipal neighbourhood.

\begin{tabular}{|c|c|c|c|c|c|}
\hline & $\begin{array}{l}\text { Time to reach the } \\
\text { stop (on foot) }\end{array}$ & Travel by public transport & $\begin{array}{l}\text { Time to reach the } \\
\text { destination (on foot) }\end{array}$ & Total time* & Total time ${ }^{* *}$ \\
\hline Option 1 & $10 \min (800 \mathrm{~m})$ & $\begin{array}{r}9 \min -\text { bus no. } 60 \\
\text { (7 stops) }\end{array}$ & $5 \min (450 m)$ & $24 \min$ & $32 \mathrm{~min}$ \\
\hline Option 2 & $13 \min (1000 \mathrm{~m})$ & 10 min- tram no. 9 & $11 \mathrm{~min}(850 \mathrm{~m})$ & $34 \min$ & $44 \min$ \\
\hline Option 3 & $7 \mathrm{~min}(550 \mathrm{~m})$ & 7 min -bus no. 80 & $14 \min (1100 \mathrm{~m})$ & $28 \min$ & $37 \mathrm{~min}$ \\
\hline Option 4 & $14 \min (1100 \mathrm{~m})$ & 7 min - bus no. 53 & $5 \mathrm{~min}(450 \mathrm{~m})$ & $26 \min$ & $35 \min$ \\
\hline \multicolumn{6}{|c|}{ Kasprowicz Park while taking into account the "less walking" option } \\
\hline Option 5 & $5 \min (400 \mathrm{~m})$ & $\begin{array}{r}3 \text { min by bus no. } 75+\text { time to } \\
\text { reach the other stop } 1 \mathrm{~min}+7 \\
\min \text { by bus no. } 53\end{array}$ & $5 \min (450 m)$ & $21 \mathrm{~min}$ & $27 \mathrm{~min}$ \\
\hline Option 6 & $5 \min (400 \mathrm{~m})$ & $\begin{array}{r}5 \text { min by bus no. } 75+\text { time to } \\
\text { reach the other stop } 1 \mathrm{~min}+ \\
\text { waiting time at the stop } 7 \text { min } \\
+8 \text { min by bus no. } 60\end{array}$ & $5 \mathrm{~min}(450 \mathrm{~m})$ & $31 \mathrm{~min}$ & $36 \min$ \\
\hline
\end{tabular}

* assuming the walking speed adopted by Google Planner Map $(1.28 \mathrm{~m} / \mathrm{s})$

** assuming the walking speed for seniors $(0,9 \mathrm{~m} / \mathrm{s})$ and changes in waiting times at stops

Source: own work based on Google maps: https://www.google.com/maps [22.07.2019].

Tab. 4. Selected possibilities of reaching Wały Chrobrego by the inhabitants of Zawadzkiego-Klonowica municipal neighbourhood.

\begin{tabular}{|c|c|c|c|c|c|}
\hline & $\begin{array}{l}\text { Time to reach the } \\
\text { stop (on foot) }\end{array}$ & Travel by public transport & $\begin{array}{l}\text { Time to reach the } \\
\text { destination (on foot) }\end{array}$ & Total time* & Total time** \\
\hline Option 1 & $15 \min (1200 \mathrm{~m})$ & 21 min- tram no. 5 (12 stops) & $9 \min (850 \mathrm{~m})$ & $45 \mathrm{~min}$ & $59 \min$ \\
\hline \multicolumn{6}{|c|}{ Wały Chrobrego while taking into account the „less walking” option } \\
\hline Option 2 & $5 \mathrm{~min}(400 \mathrm{~m})$ & $\begin{array}{r}28 \mathrm{~min} \text { by bus no. } 75+\text { time } \\
\text { to reach the other stop } 1 \mathrm{~min}+ \\
\text { waiting time at the stop } 6 \mathrm{~min}+ \\
4 \text { min by tram no. } 6\end{array}$ & $0 \mathrm{~min}$ & $44 \mathrm{~min}$ & $46 \min$ \\
\hline Option 3 & $7 \mathrm{~min}(550 \mathrm{~m})$ & $\begin{array}{r}22 \text { min by bus no. } 80+\text { time to } \\
\text { reach the other stop } 1 \mathrm{~min}+ \\
\text { waiting time at the stop } 7 \text { min+ } \\
11 \text { min by tram no. } 6\end{array}$ & $0 \mathrm{~min}$ & $48 \mathrm{~min}$ & $51 \mathrm{~min}$ \\
\hline
\end{tabular}

* assuming the walking speed adopted by Google Planner Map $(1.28 \mathrm{~m} / \mathrm{s})$

** assuming the walking speed for seniors $(0,9 \mathrm{~m} / \mathrm{s})$ and changes in waiting times at stops

Source: own work based on Google maps: https://www.google.com/maps [22.07.2019].

Tab. 5. Selected possibilities of reaching Puszcza Bukowa (Jezioro Szmaragdowe) by the inhabitants of Zawadzkiego-Klonowica municipal neighbourhood.

\begin{tabular}{|c|c|c|c|c|c|}
\hline & $\begin{array}{l}\text { Time to reach the } \\
\text { stop (on foot) }\end{array}$ & Travel by public transport & $\begin{array}{c}\text { Time to reach the } \\
\text { destination (on foot) }\end{array}$ & Total time* & Total time $^{* *}$ \\
\hline Option 1 & $15 \min (1200 \mathrm{~m})$ & $\begin{array}{r}39 \text { min- tram no. } 7 \text { ( } 22 \text { stops) + } \\
\text { time to reach the other stop } 1 \mathrm{~min}+ \\
\text { waiting time at the stop } 7 \mathrm{~min}+4 \\
\text { min by bus no. } 66 \text { ( } 66 \text { stops) }\end{array}$ & $13 \min (900 \mathrm{~m})$ & $1 \mathrm{~h} 19 \mathrm{~min}$ & $1 \mathrm{~h} 30 \mathrm{~min}$ \\
\hline Option 2 & $5 \mathrm{~min}(400 \mathrm{~m})$ & $\begin{array}{r}25 \text { min by bus no. } 75+\text { time to } \\
\text { reach the other stop } 2 \text { min }+ \text { waiting } \\
\text { time at the stop } 6 \text { min }+12 \text { min by } \\
\text { bus no. B }\end{array}$ & $24 \min (1700 \mathrm{~m})$ & $1 \mathrm{~h} 14 \mathrm{~min}$ & $1 \mathrm{~h} 23 \mathrm{~min}$ \\
\hline \multicolumn{6}{|c|}{ Puszcza Bukowa (Jezioro Szmaragdowe) while taking into account the „less walking” option } \\
\hline Option 3 & $5 \mathrm{~min}(400 \mathrm{~m})$ & $\begin{array}{r}26 \text { min by bus no. } 75+\text { time to } \\
\text { reach the other stop } 1 \mathrm{~min}+\text { waiting } \\
\text { time at the stop } 4 \text { min }+10 \text { min by } \\
\text { bus no. } B+\text { time to reach the other } \\
\text { stop } 2 \text { min }+2 \text { min by bus no. } 66\end{array}$ & $13 \min (900 \mathrm{~m})$ & $1 \mathrm{~h} 3 \mathrm{~min}$ & $1 \mathrm{~h} 10 \mathrm{~min}$ \\
\hline
\end{tabular}

* assuming the walking speed adopted by Google Planner Map $(1.28 \mathrm{~m} / \mathrm{s})$

** assuming the walking speed for seniors $(0,9 \mathrm{~m} / \mathrm{s})$ and changes in waiting times at stops

Source: own work based on Google maps: https://www.google.com/maps [22.07.2019]. 
The aim of the possible combinations presented in tables 3, 4, and 5 was the preliminary assessment of the time component of public transport. Walking speed taken by Google Planner is $1.28 \mathrm{~m} / \mathrm{s}$ whereas time to reach bus stops by the elderly could is longer. According to world literature the elderly walking speed is $3.24 \mathrm{~km} / \mathrm{h}(0.9 \mathrm{~m} / \mathrm{s})$ (Gates at al., 2006). The same speed is suggested by Duim et al. (2017). It means that part of elderly travelling by foot might be $50 \%$. In addition, the quality of the infrastructure, such as the nature of the pavement and the height of the curbs, also affects the speed of movement. The possibilities of shortening the route by using indirect connections can also be beneficial for senior citizens and as the tables show, it does not extend the total travel time to the destination.

Taking into account the financial component, it should be noted that from 2012, senior citizens from Szczecin who are aged 68-70 can buy the so-called Senior Ticket. The price of an annual ticket is PLN 60, whereas a half-year ticket costs PLN 50. Furthermore, pensioners are entitled to a $50 \%$ discount (for women aged over 55 and men aged over 60 ), while people over 70 years of age can use public transport for free. The Szczecin Senior Card enjoys considerable interest among the residents of Szczecin. In 2018, 2812 such cards were issued ${ }^{5}$.

As already mentioned in the theoretical part of the article, policies implemented at national, regional and local levels play a significant role in shaping senior-friendly transport accessibility. When referring to local documents, it is worth mentioning the document available on the official website of the city of Szczecin entitled "Sustainable Development Plan of Public Transport for the City of Szczecin for 2014-2025 - version for consultation". The authors of the document indicated the ageing society as a trend affecting the future of public transport in Szczecin. They emphasized that the offer of public transport (including rolling stock) must be adapted to the needs of this group. Although the document does not contain any provisions directly referring to senior citizens, solutions addressed to disabled people and people with reduced mobility will contribute to improving the transport accessibility of senior citizens. As part of public transport in Szczecin, it is anticipated that the actions already taken will be continued, i.e. raising platforms to a height close to the level of the vehicle floor; use of special curbs at bus stops that allow safely approaching the edge of the platform; using markings on platforms and access points; in new tram rolling stock - no narrowing of tram body in its lower

https://infoludek.pl/szczecin/podsumowanie2018-roku-w-szczecinie-w-liczbach/ [22.07.2019] part limiting the width of the gap between the entrance and the platform edge (Plan zrównoważonego rozwoju publicznego..., 2014).

Access to the municipal neighbourhood will also be improved by investments such as "Reconstruction of Arkońska str. along with the construction of the track from Arkoński Forest loop to Wojska Polskiego avenue" and "Reconstruction of ul. Szafera str. on the section from Wojska Polskiego avenue to Sports-Entertainment Hall" with the construction of a track and a new tram loop. These investments are expected to increase the attractiveness of rail transport, which will improve the accessibility of residents to public transport, shorten travel time, improve traffic flow in the city, increase the level of safety in public transport and travel comfort.

\section{Conclusions}

To sum up the above deliberations, it should be noted that the conducted literature analysis indicates that transport accessibility to public space in cities for senior citizens is becoming increasingly more often the subject of social research, which is reflected in publications related to shaping the elderly friendly transport policy. This is confirmed by scientists and researchers who have noticed the relations between changes in the demographic structure of society and the quality of life in cities. The conducted studies also underline the multidimensionality of issues related to transport accessibility in cities. Access to recreational space may include both individual access (on foot, by car or bicycle) or collective access. Moreover, time, spatial, individual and cost components can be measured, which implies research issues.

The literature lacks publications dealing with the issue of the city's recreational transport accessibility in the context of the needs of the elderly. Nevertheless, the relations between recreational activity of senior citizens, transport accessibility and quality of life are beginning to be noticed. There is no doubt that the improvement of transport accessibility to recreational space in cities for senior citizens is an important factor conducive to social activation of this group of people which also prevents social exclusion of this group. In the near future, senior citizens will constitute the dominant group of city dwellers, and their activity related to mobility will have an impact on the socio-economic development of the city. The improvement of transport accessibility to specific places should increase the traffic in these places and at the same time their attractiveness. In the case of recreational spaces, this may involve a decrease in the seasonality of their use. Moreover, it should be emphasized that the introduction of solutions improving 
the comfort of senior citizens' travel will contribute to a higher travelling comfort of other people. In order to determine the possibilities of supporting the use of public transport by senior citizens, it is necessary to conduct qualitative research and examine transport behaviour of senior citizens, which will allow indicating socio-economic linkages and areas of intervention. Observations and analyses show that city authorities understand the need to introduce innovative solutions addressed to senior citizens regarding urban transport. However, these activities are still insufficient. Some are conducive to improving the accessibility of only some of senior citizens, for example the possibility of buying a ticket in a stationary ticket machine, or reading the timetable using the introduced QR codes. Although senior citizens should not be perceived stereotypically, the use of ticket machines or applications may constitute a problem for a large part of them. Moreover, it seems reasonable not only to introduce improvements but also to carry out activities aimed at changing the negative perception of public transport by senior citizens.

\section{References}

Badania statutowe: Miasto jako obszar aktywności turystycznej i rekreacyjnej, na przykładzie Szczecina. Etap III. Aktywność rekreacyjna mieszkańców szczecina, Uniwersytet Szczeciński (materiały niepublikowane).

Bocheński T., 2018, Badania dostępności transportowej ze szczególnym uwzględnieniem kolei, „Stare i nowe" problemy badawcze w geografii społecznoekonomicznej, Sitek S. (ed.), No. 8, Polskie Towarzystwo Geograficzne Oddział Katowicki, Uniwersytet Śląski Wydział Nauk o Ziemi, Sosnowiec, 103-121.

Dalvi M. Q., Martin K. M., 1976, The measurement of accessibility: some preliminary results, Transportation, 5(1), 17-42.

Dawid W., 2019, Dostępność i jakość przestrzeni publicznych w tkance miejskiej wybranych dzielnic Krakowa w kontekście użytkowania ich przez osoby starsze, Prace Geograficzne, 156, 101 - 119. (DOI 10.4467/20833113PG .19.005.10309)

Duim, E. Lebrão M. L., Ferreira Antunes J. L., 2017, Walking speed of older people and pedestrian crossing time, Journal of Transport \& Health, 5, 70-76. (DOI 10.1016/j. jth.2017.02.001)

Gates T. J., Noyce D. A., Bill A. R., Van Ee N., 2006, Recommended Walking Speeds for Timing of Pedestrian Clearance Intervals Based on Characteristics of the Pedestrian Population, Transportation Research Record: Journal of the Transportation Research Board, 1982(1), 38-47. (DOI 10.1177/0361198106198200106)

Hansen W. G., 1959, How accessibility shapes land use, Jour- nal of the American Institute of Planners, 25, 73-76. (DOI 10.1080/01944365908978307)

Komornicki T., Śleszyński P., Rosik P., Pomianowski W., 2009, Dostępność przestrzenna jako przesłanka kształtowania polskiej polityki transportowej, Biuletyn PAN KPZK, 240, PAN, Warszawa.

Komsta H., Droździel P., Rybicka I., Madlenak R., 2017, Rola transportu publicznego w kształtowaniu miasta przyjaznego osobom starszym, Autobusy, 12, 564-569.

Kruszyński M, Żak J., 2017, Analiza i ocena wielokryterialna wybranych, innowacyjnych rozwiązań transportowych wobec potrzeb osób z niepełnosprawnością i starszych, Zeszyty Naukowe Politechniki Poznańskiej Organizacja i Zarządzanie, 75, 141-162. (DOI 10.21008/ j.0239-9415.2017.075.11)

Kwarciński T., 2013, Dostępność usług transportowych jako kryterium oceny publicznego regionalnego systemu transportowego, Studia Ekonomiczne, 143, 230-236.

Olszewski P., Dybicz T., Śleszyński P., 2013, Proponowane miary dostępności czasowej w transporcie publicznym, Przegląd Komunikacyjny, 12, 10-17.

Panek T., Zwierzchowski, R., 2019, Analiza porównawcza jakości życia w Polsce w układzie wojewódzkim w ramach podejścia możliwości, IDSiD Working Papers, Instytut Statystyki i Demografii SGH, Warszawa.

Raczyńska-Buława E., 2017a, Osoby starsze a miejski transport publiczny. Problemy i bariery mobilności, Autobusy, 1-2, 26-36.

Raczyńska-Buława E., 2017b, Mobilność osób starszych. Dlaczego nie transport publiczny?, TTS Technika Transportu Szynowego, 24(1-2), 24-33.

Sawińska A., 2018, Management of senior citizens leisure time as the challenge of modern cities illustrated by the example of Szczecin, European Journal of Service Management, 27(3), 255-262. (DOI 10.18276/ejsm.2018.27/132)

Shiau T.-A., Huang W.-K., 2014, User perspective of agefriendly transportation: A case study of Taipei City, Transport Policy, 36, 184-191. (DOI 10.1016/j.tranpol.2014.08.010)

Sierpiński G., 2010, Miary dostępności transportowej miast i regionów, Zeszyty Naukowe Politechniki Śląskiej, 66, 91-96.

Solecka K., 2018, Potrzeby osób starszych w zakresie mobilności w mieście, Autobusy: technika, eksploatacja, systemy transportowe, 19(6), 1251-1259. (DOI 10.24136/ atest.2018.262)

Śniadek J., Zajadacz A., 2014, Turystyka i rekreacja a jakość życia mieszkańców Leszna, Zeszyty Naukowe Uniwersytetu Szczecińskiego, Ekonomiczne Problemy Turystyki, 1(25), 341-365.

TRACY, Transport needs for an ageing society, Final Report, 2013, https://cordis.europa.eu/docs/results/285613/final1-d5-4-3rd-summary-paper-action-plan-accessible. pdf [20.07.2019] 
Trzpiot G., Szołtysek J., 2015, Analiza preferencji jakości życia seniorów w miastach, Studia Ekonomiczne. Zeszyty Naukowe Uniwersytetu Ekonomicznego w Katowicach, 248, 257-274.

\section{Websites}

https://dzielniceszczecina.tv-polska.eu/film3/402763dzielnice-szczecina-z-drona---zawadzkiego-klonowica\#osiedla [22.07.2019]

https://infoludek.pl/szczecin/podsumowanie-2018-rokuw-szczecinie-w-liczbach/ [22.07.2019]

https://cordis.europa.eu/news/rcn/128538/pl [15.07.2019] https://www.zditm.szczecin.pl [20.07.2019]

https://dpsromera.szczecin.pl/ [22.07.2019]

https://www.google.com/maps [22.07.2019]

http://geoportal.szczecin.pl [23.09.2019]

Plan zrównoważonego rozwoju publicznego transportu zbiorowego dla Miasta Szczecin na lata 2014-2025 - Projekt, 2014, http://bip.um.szczecin.pl/UMSzczecinFiles/ file/PZRPTZ_SZCZECIN_2014_4.pdf [20.07.2019]

Report of the Task Force: Multidimensional measurement of the quality of life, Sponsorship Group on Measuring Progress, Well-being and Sustainable Development, 2011, Eurostat, https://ec.europa.eu/eurostat/documents/8131721/8131772/TF3-Final-report-Quality-ofLife.pdf [25.09.2019] 